\title{
Environmental policies and efforts in social housing: the Netherlands
}

\author{
Minna Sunikka and Claudia Boon \\ OTB Research Institute for Housing, Urban and Mobility Studies, Delft University of Technology, \\ Thijsseweg 11, 2629 JA Delft, The Netherlands \\ E-mail: sunikka@otb.tudelft.nl
}

\begin{abstract}
Although progressive government guidelines and awareness of sustainable issues exists, progress in sustainable management in the social housing sector has been slow. A market research survey and analysis of the sustainable housing management by Dutch housing associations indicates the areas and organizations where policies, instruments and practices are focussed or lacking. Longitudinal trends are established using further surveys from 1993, 1998 and 2000 as well as comparing national strategies from five European Union countries (the Netherlands, Germany, the UK, France and Finland). Results indicate that efforts in sustainable management are misplaced with emphasis on procuring new buildings, not on operation and maintenance. Several barriers at the policy and strategy level are identified, especially the perceived costs of implementing environmental management, the lack of market demand and the poor capture of benefits. Special recommendations for government, housing associations and occupants are based on the findings - widening the focus of issues on sustainability, emphasizing the existing building stock, increasing the use of voluntary agreements, recognizing different capabilities in scale of housing associations and creating market demand.
\end{abstract}

Keywords: building stock, environmental policy, housing associations, management, social housing, sustainable built environment, the Netherlands

\begin{abstract}
Bien qu'il existe des directives gouvernementales progressives et que l'on soit conscient des questions de durabilité, le progrès en matière de gestion durable au sein du secteur du logement social a été assez lent. Une analyse et une étude de marché portant sur la gestion du logement durable menées par des associations hollandaises pour le logement indiquent les domaines et les organisations où les principes, les instructions et les pratiques sont limités ou absents. Des tendances longitudinales se dégagent sur la base d'autres études menées en 1993, 1998 et 2000 et qui comparent les stratégies nationales de cinq pays de l'Union Européenne (Pays-Bas, Allemagne, Royaume-Uni, France et Finlande). Les résultats montrent que les efforts en matière de gestion durable sont mal orientés, l'accent étant mis sur la fourniture de bâtiments nouveaux et non sur leur exploitation et leur maintenance. L'article recense plusieurs obstacles aux niveaux politique et stratégique, notamment en ce qui concerne les coûts perçus de la mise en œuvre d'une gestion de l'environnement, le manque de demande du marché et la capture médiocre des bénéfices. Des recommandations particulières à l'attention du gouvernement, des associations pour le logement, des occupants reposent sur ces conclusions-; il faudrait notamment élargir le cœur des problèmes à la durabilité, mettre l'accent sur le parc immobilier existant, avoir recours davantage à des accords volontaires, reconnaître les différentes capacités parmi les associations pour le logement et susciter la demande du marché.
\end{abstract}

Mots clés : parc immobilier, politique environnementale, associations pour le logement, gestion, logement social, cadre bâti durable, Pays-Bas

\section{Introduction}

In the European Union, buildings account for over $40 \%$ of the total current energy consumption and $30 \%$ of all carbon dioxide $\left(\mathrm{CO}_{2}\right)$ emissions (Bourdeau,
1999). The Kyoto Protocol has increased pressure on governments in various countries to establish sustainable building strategies aimed at reducing $\mathrm{CO}_{2}$ emissions. Sunikka (2001) studied the impact of national 
strategies in five countries that have adopted sustainability strategies for the construction sector: the Netherlands, Germany, France, the UK and Finland. Current policies in all five countries focus exclusively on new construction, which adds roughly $1 \%$ annually to the total building stock. In addition, Waals et al. (2000) concluded that the real potential for sustainable building and $\mathrm{CO}_{2}$ reduction lies in managing the existing stock of residential buildings, and that housing associations, as managers of a large segment of the total housing stock, are key actors in fulfilling this potential. This area, however, has been largely ignored in current research and development activities.

Housing associations in the Netherlands are presented as a case study. The Dutch housing sector, $36 \%$ of which consists of social housing (Haffner and Dol, 2000), faces the task of reducing its $\mathrm{CO}_{2}$ emissions by 25 million tonnes between 2000 and 2012. This target can only be achieved through large-scale renovation of the existing housing stock, which for housing associations requires an environmental policy and action plan.

The Dutch situation is situated in a broader context. Using a comparative analysis, environmental efforts in the social housing sector are examined in Germany, France, the UK and Finland. These countries were selected because they have comparable policies on but different approaches to - sustainable building. An empirical analysis concentrating on the Dutch situation provides insight into the environmental policies of housing associations, the instruments used and sustainable measures taken during maintenance, renovation, refurbishment, demolition and new construction. Drawing on similar research studies in 1993 and 1998, this analysis also examines developments in sustainable housing management that have emerged in Dutch housing associations since 1993. Finally, the opportunities for sustainable building and sustainable management in the social housing sector are discussed.

\section{Background \\ The Netherlands}

Two Action Plans have been published for sustainable building in the Netherlands (MVROM, 1995, 1997). In addition to building regulations, the government uses other measures to stimulate the implementation of the strategy. However, the Action Plans for Sustainable Building do not set specific targets for the social housing sector in particular, a sector that accounts for $75 \%$ of the total rental stock and includes 2.3 million homes (Haffner and Dol, 2000). Social housing associ- ations themselves have been searching for ways to promote sustainability. Aedes, the umbrella organization for social housing associations, entered into an environmental agreement with the government on behalf of its members in 1998 and has developed strategies to translate the objectives into an environmental policy at the housing association level (Quintis, 1999). According to Luten and van Bakel (1997) and Weissman (2000), costs and a lack of knowledge, appropriate instruments and information have been the primary factors preventing sustainability from really becoming established as common practice in the social housing sector.

\section{Germany}

Unlike most countries, Germany's sustainable building strategy relies mainly on norms and regulations (Liimatainen, 1995). According to the Federal Statistical Office (2000), Germany's stringent, long-term environmental policy has achieved partial results in terms of stabilizing energy consumption and regenerating waste despite economic growth. The volume of social housing in Germany is relatively small, accounting for $15 \%$ of the total housing stock (Haffner and Dol, 2000). Building regulations ensure that social housing providers observe certain environmental measures, including renovations. Thus, they do not have the freedom to pursue environmental policies and invest in sustainable improvements based on their resources. All social housing providers must observe certain ecological standards to meet the housing subsidy criteria. The environmental ambition level for the subsidy criteria is higher than the building regulations. The financial impact of German public policy will soon be reflected in the social housing sector with the introduction of new thermal regulations. These regulations will also apply to the existing stock, and the renovation expenses anticipated as a result.

\section{France}

France has yet to develop an action programme for sustainable building, despite an initiative known as the Haute Qualite Environnementale (High Environmental Quality) led by the Association HQE (2000). Sunikka (2001) found no special HQE legislation or nomenclature; sustainability is a relatively new issue in France, and general consumer patterns and attitudes are not yet very ecological. Social rental housing accounts for $46 \%$ of the total rental stock in the country (Haffner and Dol, 2000) and can, therefore, efficiently promote sustainable building. Delebarre (2000) reported that French social housing providers 
made a commitment to the principle of sustainable development by adopting an environmental policy in 2000. While the policy targets are ambitious, they have been formulated descriptively. Without measurable objectives, monitoring will be difficult. The social housing sector, the National Agency for the Environment and Energy Management, and Gaz de France, the state-held gas company, have entered into environmental agreements that provide for incentives towards introducing energy and waste improvements in social housing. Value-added tax (VAT) can be reduced for renovation projects in France, a provision that has enabled investments in energy efficiency.

\section{The UK}

The UK's strategy for sustainable construction is market-driven and linked to the improvement of competence in the construction industry (DETR, 2000). The problem with the industry-orientated approach is that market actors alone are unlikely to promote sustainable construction when the market for it is still weak (Sunikka, 2001). The social housing sector, which accounts for $60 \%$ of the total rental stock (Haffner and Dol, 2000), endeavours to support government policy in its actions. The Housing Corporation (2000), which regulates and funds the Registered Social Landlords in England, published its Environmental Policy in 2000. The policy emphasizes integrating sustainability in all actions and criteria in the Corporation. As the targets are mainly descriptive, only time will tell whether the Environmental Policy will effect concrete change in current practices and how progress will be monitored. Given the recent decline in the government's influence on social housing, housing associations need to be motivated with environmental incentives and subsidies, a measure that has yet to be widely adopted in the UK.

\section{Finland}

The Finnish strategy in promoting sustainable construction relies heavily on the environmental awareness prevalent in the market. Ympäristöministeriö, the Ministry of the Environment (1998), published its Programme for Ecologically Sustainable Construction in 1998. Unlike the other countries studied in this overview, Finland has no umbrella organization for the social housing sector, which accounts for $48 \%$ of the total rental stock (Haffner and Dol, 2000). Finland's Housing Fund, which issues state loans and approves interest subsidies for social housing, aims to integrate environmental issues in the subsidy criteria in the near future. If this plan is actually implemented, it will make social housing providers very conscious about sustainable building.

\section{Conclusions}

This brief overview of these five European countries shows that each country's social housing sector appears to be aware of the role it can play in promoting sustainable building. However, current government strategies for sustainable building are general and voluntary. Moreover, they fail to pay adequate attention to the issue of renovating and managing the existing housing stock. While the social housing sector is often mentioned as a major target group, government strategies do not address objectives for that sector in particular. Consequently, social housing providers see government policies more as general guidelines than as action plans, which require changes in current practice. For this reason, the environmental approach has remained cautious in practice in all five countries.

\section{Methodology}

The Netherlands was chosen as a case study because of its large social housing sector and its experience in sustainable building. Of the five countries analysed, the Netherlands had the most developed sustainable building policy in its social housing sector (Sunikka, 2001). The description of practical sustainable management in the Dutch social housing associations is based on four surveys. This section describes how the survey data were obtained and used.

In 1998, the Dutch social housing sector, the Dutch government and a few third parties drew up the Sustainable Building Agreement, which includes a survey programme for the evaluation of environmental objectives. In the 2000 survey, 700 housing associations were sent a questionnaire addressing the qualitative and quantitative aspects of sustainable management, with 190 responding (Atrivé, 2001). The pool of respondents varied from housing associations that managed fewer than 500 dwellings to some in charge of over 10000 . The size of a housing association is likely to have some impact on how actively it implements the sustainable building agreement. Note that each answer was analysed in relation to how many dwellings the respondent managed. The anonymous questionnaire and limited number of questions limited the potential to make statistical cross-analyses, such as the managed stock and adaptation of an environmental policy.

This paper focuses on the results of the 2000 survey and examines the results of the corresponding survey 
in 1998, where 763 housing associations received the questionnaire and 316 responded (Atrivé, 1998).

Two other surveys were studied, which provide an overall picture of developments in sustainable housing management in the Netherlands. In 1993, Quist and van den Broeke (1994) conducted the Sustainability and Housing Maintenance Research Study for the Ministry of Housing, Spatial Planning and the Environment. One of the research objectives was to gauge the status quo in sustainable housing management and the environmental performance of social housing. Altogether, 253 housing associations and 362 commercial landlords were interviewed in connection with that study. The 1993 results are used as a reference source for the present study. This places the 1998 and 2000 survey results in a time perspective, and it enabled the examination of developments between 1993 and 2000.

At the beginning of 2001, Stichting Bouwresearch (SBR) (2001) conducted an extensive study into attitudes towards sustainable building among municipalities and market actors, including housing associations. In total, 2341 questionnaires were received and analysed; 225 of those were from the housing associations. The SBR market research study enables an interesting comparison with the survey results, as the answers of the housing associations can be compared with those of other market actors, such as developers, architects and contractors. We will refer to the results of this market research study throughout.

\section{Sustainable management in the Netherlands}

\section{Environmental policies in housing associations}

One-third of the housing associations that responded to the questionnaire have an environmental policy (Figure 1). However, this figure does not completely reflect what actually happens in practice, since housing associations can implement environmental measures without necessarily adopting an environmental policy. In total, $75 \%$ of the social housing associations indicated that they implemented environmental measures regularly, and $15 \%$ through experiments. Eight per cent of the housing associations implemented no sustainable measures. According to the cross-analyses, this group consisted mostly of small associations. On average, the housing associations with environmental policies were one-third bigger than those with no such policies. As shown in Figure 2, the more dwellings a housing association managed, the more environmental policies it tended to adopt.

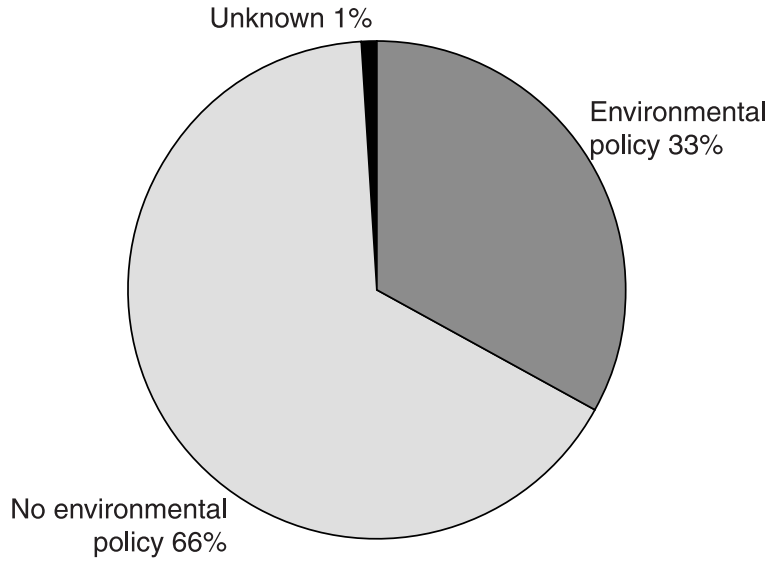

Figure 1 Environmental policies in Dutch social housing associations in 2000. Source: Atrivé (2001)

A correlation was found between the size of housing association and the implementation of environmental measures (Sunikka and Boon, 2002). Approximately $60 \%$ of the housing associations in the two smallest categories implemented environmental measures, whereas nearly all of the associations managing over 1800 dwellings implemented them. However, the housing associations managing over 10000 dwellings were not very active in implementing environmental measures despite their great capacity.

The housing associations were subsequently asked which environmental measures they would consider in new buildings and the existing stock. Energy and materials were the most popular measures to be implemented both in new and existing dwellings in 2000. However, the energy measures were based more on building regulations than on any initiative towards investing in experimental measures. Energy Performance Coefficient $(\mathrm{EPC})^{1}$ values $<1$, which is the current building regulation level, are uncommon in new dwellings, even though the housing associations like to cite energy saving as a priority in their environmental policies. This implementation of building regulations can hardly be considered sustainable building. Solar panels are still rare in practice, and solar collectors were implemented in $8 \%$ of the new dwellings in 2000. Despite their well-established position in sustainable building, good indoor quality and water-saving measures receive little attention in the housing associations, and are seldom implemented in practice. Flexibility, accessibility and safety measures are relatively popular, especially in new dwellings.

Environmental measures often become a focus of attention during the early phases in new construction, 


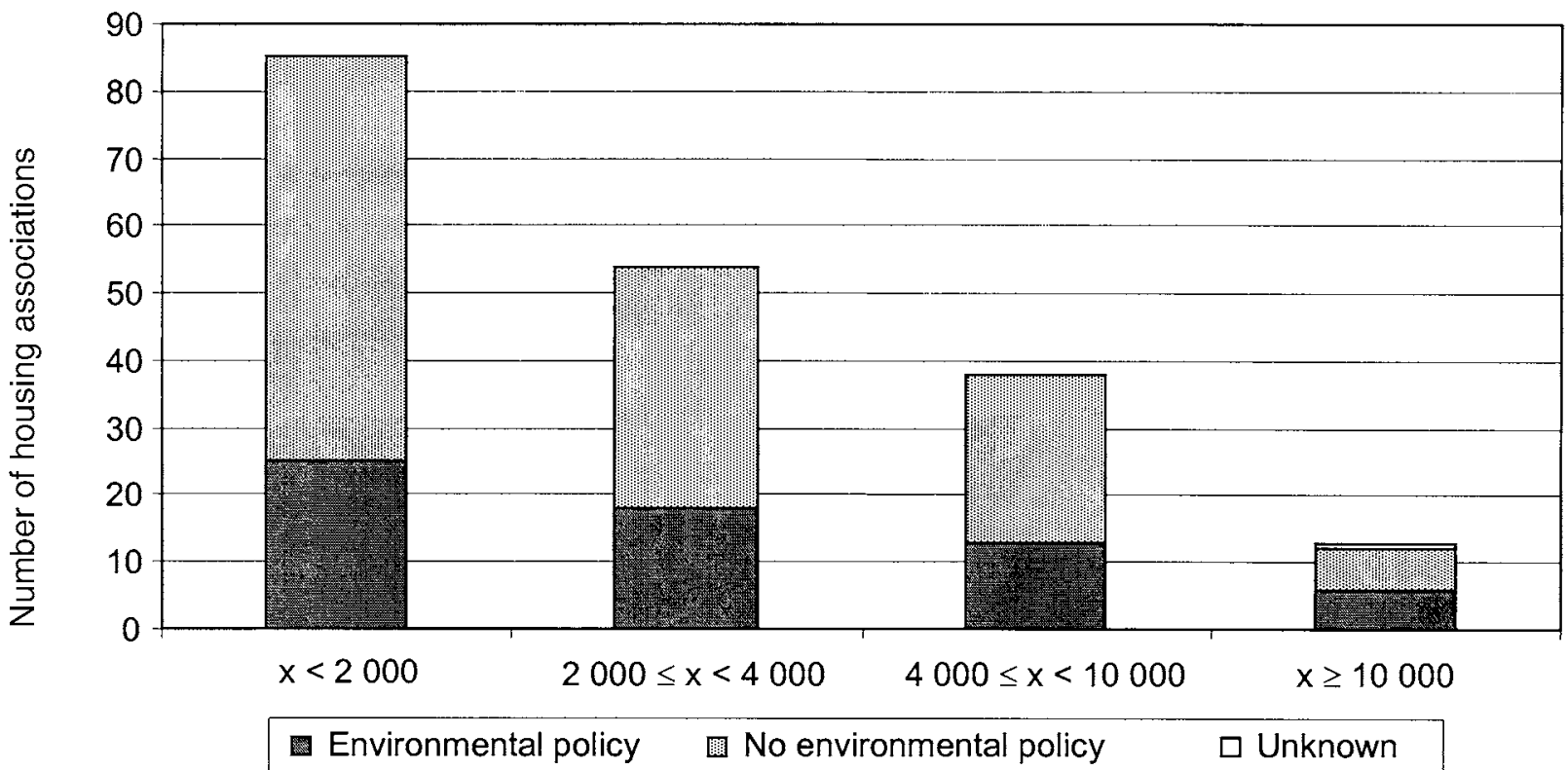

Figure 2 Environmental policies in Dutch social housing associations in relation to the number of managed dwellings in 2000. Source: Sunikka and Boon (2002)

and in major projects in existing stock, such as renovations. Daily maintenance and demolition are the phases where sustainability receives less consideration. Sunikka and Boon (2002) concluded that this lack of attention to the existing stock poses a serious disadvantage to the future of sustainable building, as much can be done to benefit the environment with existing dwellings.

\section{Use of sustainable management tools}

In the Netherlands, a number of tools and methods have been developed for sustainable housing management, such as the National Packages for Sustainable Building, Duwon, Energy profile and Energy Performance Advice (EPA) (Sunikka and Klunder, 2001). The National Packages for new housing and management (SBR 1998a, b) consist of sets of measures and recommendations for achieving sustainable building. Measures in the National Packages relate to materials, energy, water and the indoor climate. The introduction of the National Packages brought about consensus about the definition of sustainable building between the construction industry, product manufacturers, developers and government authorities in the Netherlands. However, the results of these measures in terms of reducing the burden on the environment are still relatively modest on average (Blaauw and Klunder, 1999). Duwon (SEV, 1997) is a manual that aids housing managers and decision-makers in taking account of environmental performance as a quality aspect in complex decision-making processes. The EPA has been developed to provide insight into the current energy performance of existing dwellings when recommended energy measures are implemented.

Figure 3 shows that the National Housing Package was the most popular package used in the housing associations in 2000. The National Package for Management and Duwon were used less, although those who did opt for them rated them as useful.

A total of $69 \%$ of the users rated Duwon as sufficient or good, and $14 \%$ as fair. None of the users gave it a bad rating. However, $61 \%$ of the respondents were unfamiliar with Duwon or had no opinion about the tool. The EPA was developed for energy efficiency in the existing stock. Over $50 \%$ of the housing associations use the EPA, which gained popularity in a relatively short period owing to its well-organized system and subsidy provisions. Therefore, the EPA is a useful model to follow in developing new methods to promote sustainable building. A total of $38 \%$ of the housing associations rated it as good and $47 \%$ as sufficient. A cross-analysis revealed these tools are used more in large housing associations than in the small associations. The average user of the National Housing Package is almost three times larger than non-users. Duwon users are six times larger than their non-user counterpart housing associations. 


\section{Environmental agreements}

Two types of policies define sustainable building in the Netherlands: legislation for energy efficiency and convenants, which are voluntary agreements for sustainable building in general. These convenants are drawn up mainly for the purpose of establishing agreements with different parties on sustainable building. Deliberation among the parties involved is important in the process. These agreements are used to complement legislation, but have no legal status and are voluntary. Figure 4 shows that most of the environmental agreements are drawn up between housing associations and municipalities.

The voluntary agreements focus on energy, but also cover other measures. Nearly $50 \%$ of the housing associations have entered into an agreement with energy providers to realize energy-saving objectives. Strikingly, energy is well covered in each agreement. In contrast, the practice of establishing agreements with other housing associations and water-saving companies is less popular. The agreements between the housing associations and municipalities focus on new building. In the SBR market research study (2001), housing associations were asked whether their agreements cover construction of new dwellings and utility buildings and renovations of existing dwellings and utility buildings. According to the housing associations, $92 \%$ of their sustainable building agreements concern new dwellings, and only 55\% renovations. Some housing associations consider both new building and renovation, but most of them focus only on new construction.

Cross-analyses relating the answers to the managed stock showed that the small housing associations enter into fewer agreements than their larger counterparts. The housing associations that have agreements with municipalities are, on average, almost two times larger than those who do not. Are housing associations that have entered into agreements with municipalities more active in implementing sustainable building measures than those who have not such agreements? A crossanalysis revealed that $42 \%$ of the housing associations that have established an agreement with a municipality have adapted an environmental policy; the figure was only $18 \%$ for those with no such agreement. Furthermore, $89 \%$ of the housing associations that have an agreement with a municipality use the National Housing Package and $42 \%$ of them provide environmental education for their tenants. The latter percentage is double the housing associations without such agreement.

\section{Environmental education of tenants}

Tenants play an essential role in reducing the environmental impact of dwellings during their operation and

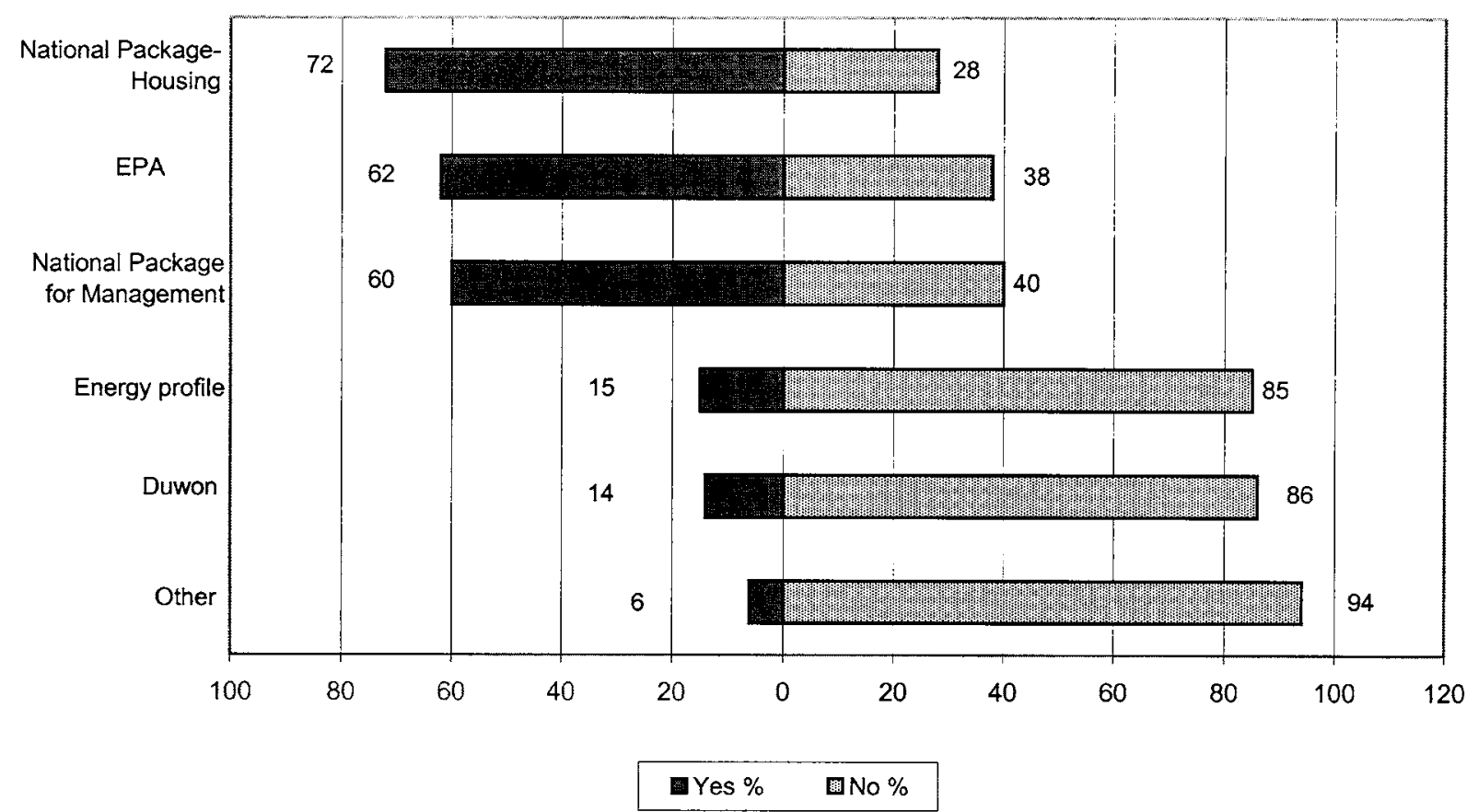

Figure 3 Use of sustainable management tools in Dutch social housing associations in 2000. Source: Atrivé (2001), Sunikka and Boon (2002) 


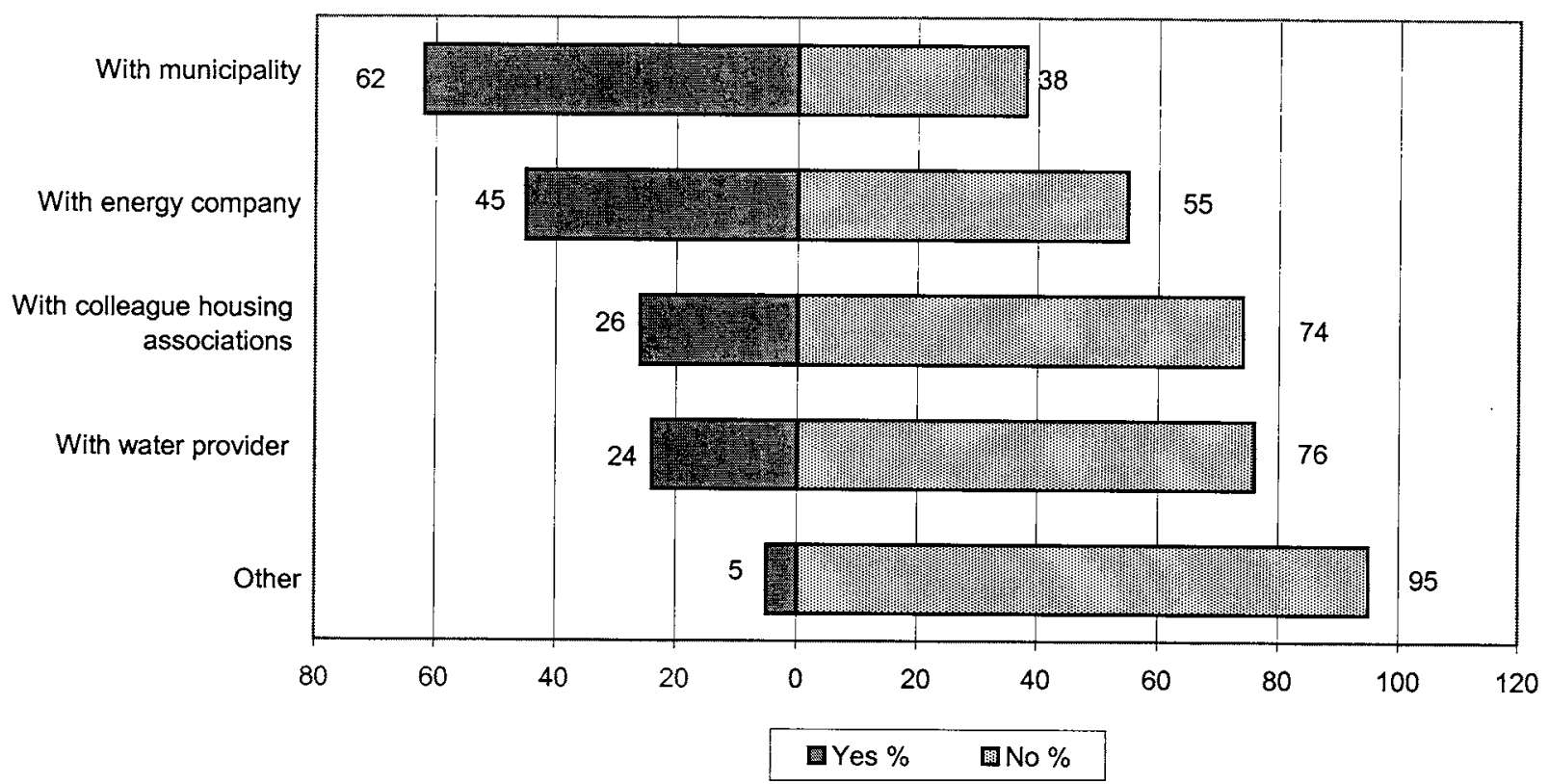

Figure 4 Environmental agreements in Dutch social housing associations in 2000. Source: Atrivé (2001), Sunikka and Boon (2002)

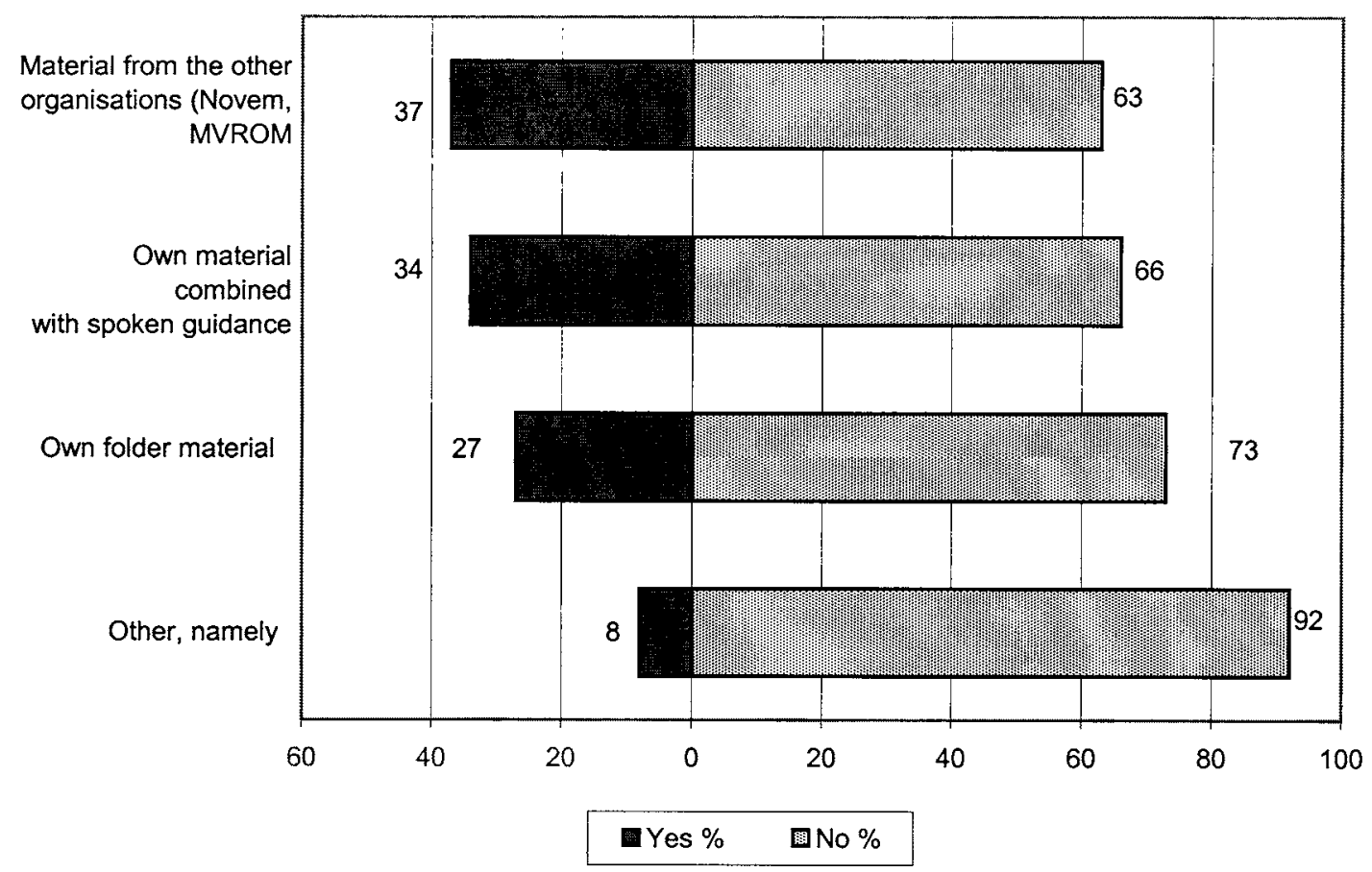

Figure 5 Environmental education of tenants in Dutch social housing associations in 2000. Source: Atrivé (2001), Sunikka and Boon (2002)

maintenance. Housing associations can educate their tenants about energy efficiency, water saving and other subjects by providing their own material to tenants or by making use of other organizations such as the Ministry of the Environment. The results in Figure 5 indicate that in 2000, one-third of the housing associations provided energy-related environmental education materials for their tenants. Considering the volume of education materials already available about sustainable building, this is relatively little. 


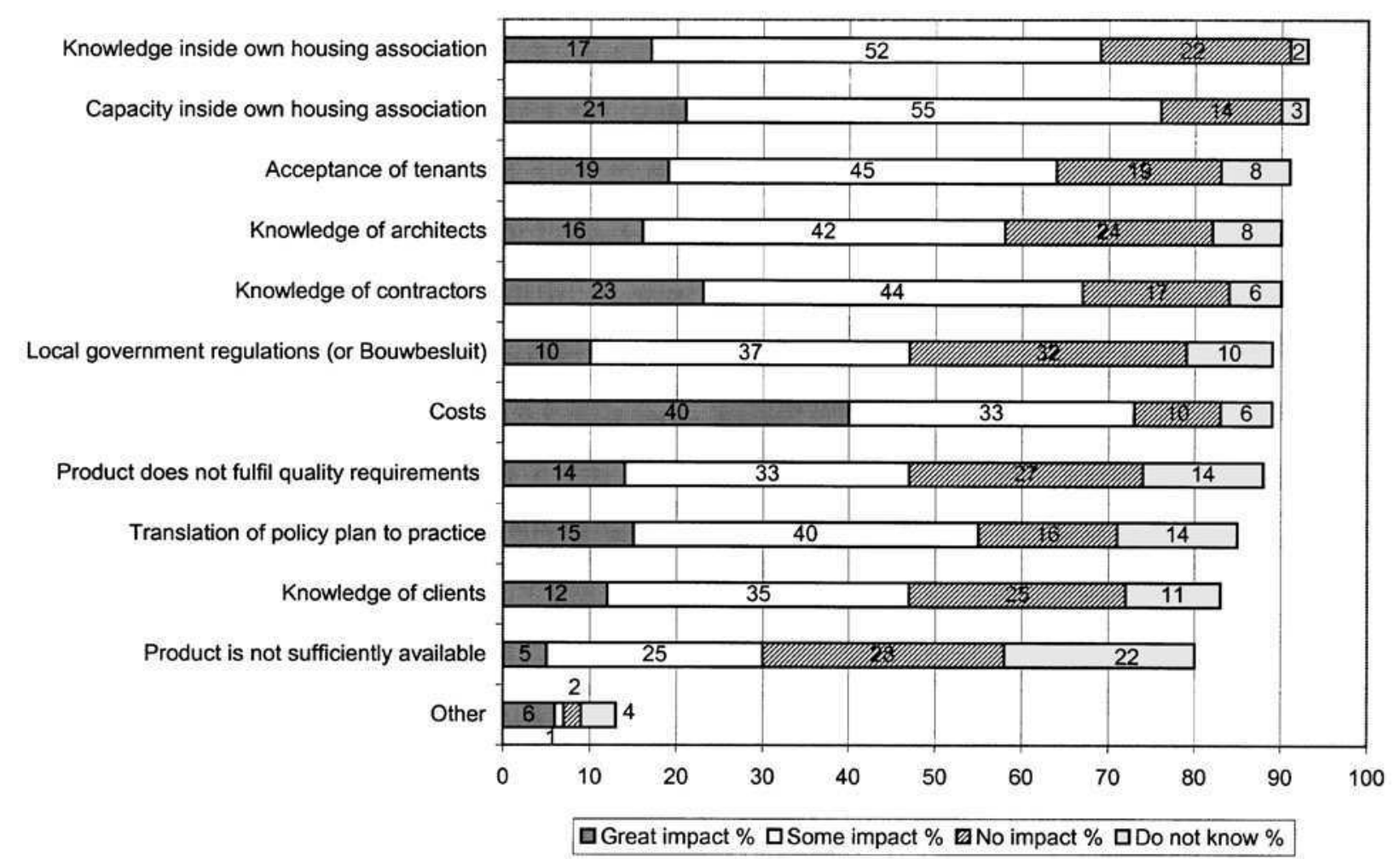

Figure 6 Barriers to sustainable management in Dutch social housing associations in 2000. Source: Atrivé (2001), Sunikka and Boon (2002)

Cross-analyses on environmental policies showed that housing associations with environmental policies are slightly more active in providing environmental education to their tenants than those without such policies. In total, $37 \%$ of the respondents with environmental policies have invested efforts in environmental education; for those without policies, the figure was $22 \%$.

The SBR market research study (2001) shows that consumers are not very interested in sustainable building in the Netherlands. According to the housing associations, $33 \%$ of their tenants are interested or very interested in sustainable building, $49 \%$ are somewhat interested, 9\% have no interest whatsoever and 9\% do not have an opinion. Furthermore, of those tenants who are interested in sustainable building, only a few are willing to invest extra money in it. The housing associations that participated in the survey estimated that $16 \%$ of their tenants would be prepared to pay extra for environmental measures, and indicated that $6 \%$ would actually request sustainable building. Thus, the SBR market research study shows that most organizations and companies do not want to establish their profile as being associated with sustainable building. Only $6 \%$ of the housing associations indi- cated that they always associate sustainable building with their profile. Another $38 \%$ claimed to do so often, $41 \%$ sometimes or rarely, $14 \%$ never and $3 \%$ did not have an opinion.

\section{Barriers to sustainable housing management}

The above research results indicate that sustainable building is an issue well familiar to social housing associations in the Netherlands. However, it is still implemented modestly in practice. To find effective ways to improve this situation, barriers must be recognized and appropriate support measures introduced. The most important barriers to sustainable housing management in 2000 were the demands individual housing associations faced in terms of costs, capacity and knowledge (Figure 6). The quality and availability of the product, and building regulations are seen as less of a barrier. Architects' and contractors' knowledge and capabilities are considered as more of a barrier than clients' knowledge.

Cross-analyses showed that approximately $75 \%$ of the housing associations with environmental policies found the process of translating policy into practice to pose a partial or major barrier. No correlation 
between the consideration given to barriers and the size of managed stock was found.

\section{Developments in sustainable management}

A comparison of the 2000 survey results with those for the 1993 and 1998 surveys shows, despite developments in national strategy, sustainable management in Dutch housing associations has developed little since 1993, and certainly not since 1998. Quantitative information about the measures implemented in 1998 and 2000 supports this finding. Housing associations spent an average of $€ 2968$ per dwelling in sustainable building measures in new construction in 2000, and $€ 71$ per dwelling in the existing stock. As compared with 1998, the investment decreased by $25 \%$ in 2000. Watersaving measures showed a decline. Why sustainable management has not really improved is a question that requires deeper study. It should be noted, however, that attitudes have changed since 1993, with the focus increasingly on costs. In the SBR market research study (2001), 43\% of the housing associations cited subsidies as an important stimulation measure. They named subsidies more often than did other market actors, such as developers or contractors. However, according to Sunikka and Boon (2002), positive trends have also arisen. One major development to emerge since 1993 is the practice of drawing up environmental agreements with third parties. In that year, $6 \%$ of the housing associations named sustainable building agreements as a measure for developing and implementing environmental policies. By 1998, over 50\% of the housing associations had established sustainable building agreements with municipalities, and $40 \%$ with energy companies. A change has also emerged in the use of tools. The current tools did not exist in 1993. In 1998, $66 \%$ of the housing associations used the National Housing Package and $41 \%$ the National Package for Management. Since 1998, the use of tools has continued to increase.

\section{Conclusions}

Sustainable management in the Dutch social housing associations was examined, because it already has experience of sustainable building policies. Although systems of social housing differ between countries, certain measures can be transferred from the Netherlands to Germany, France, the UK and Finland. Conditions in the Netherlands and the UK are similar enough for mutual exchange. Although the volume of German social housing is relatively small, these measures could be adapted and applied very success- fully in a country with a larger volume of social housing. Sustainable housing management in Finland and France is fairly out-dated compared with the Netherlands, although several development activities are under way in this area. Analysis of the Netherlands led to several conclusions about sustainable management in the social housing sector which could be used to encourage sustainable building across Europe:

\section{Cost is a primary barrier}

Although research showed that housing associations have positive attitudes towards sustainable building, by 2000 sustainable management had not yet been successfully implemented in the Netherlands' social housing sector. A comparison of the results from the surveys conducted in 1993, 1998 and 2000 indicates housing associations have not made much progress since 1993 in implementing sustainable management despite developments in government strategy, building regulations and incentives. The housing associations themselves cite the main barriers to sustainable housing management as costs, capacity and knowledge and the problem of acceptance by tenants. For most housing associations, cost is the primary reason for the slow implementation of sustainable building in daily practice. All five countries analysed recognized this conflict between environmental and economic values. In many countries, the market situation has changed radically in recent years, with housing associations increasingly expected to generate profits. Environmental investments are strictly limited by tight budgets as European social housing providers face the challenge of surviving within the market.

\section{Sustainability management is too narrowly focused}

Our research shows that, in total, $75 \%$ of Dutch housing associations implement sustainable building measures regularly, $15 \%$ through experiments, but less than half these housing associations have adopted an environmental policy. Material and energy-related measures are relatively well adopted in practice, especially in new buildings, whereas good indoor quality and water-saving measures receive little attention. The research results indicate that when housing associations actually implement environmental measures, the target level of the building regulations is seldom exceeded. Moreover, efforts towards sustainability are presently concentrated more in separate experiments than in systematic management, both in the Netherlands and the four European countries analysed. 


\section{Insufficient attention to the existing building stock}

There is a lack of attention in the Netherlands to the existing stock in terms of sustainable housing management. Furthermore, sustainable building measures considered in the existing stock are usually in renovation, whereas in maintenance and operation phases sustainability is ignored. However, substantial environmental profit can be derived from existing dwellings. This situation, which is similar in Germany, France, the UK and Finland, is a serious disadvantage for the future of sustainable building. Therefore, ways to stimulate the renovation of existing stock should be sought.

\section{Current tools for sustainable management are useful} A comparison of the survey results shows that since 1998 Dutch housing associations have increasingly used tools such as the National Packages for Sustainable Building, Duwon and EPA. Furthermore, these tools were still rated as quite useful in 2000. The EPA focuses on energy conservation and was developed to provide insight into the current energy performance of existing dwellings when recommended energy measures are implemented. If housing is rated using the EPA, an extra subsidy of $25 \%$ is granted for any measures recommended. Over $50 \%$ of the housing associations use this tool, which gained popularity over a relatively short period due to its well-organized system and subsidy provisions. The EPA is a useful model to follow in developing new methods to promote sustainable building both in the Netherlands and elsewhere in Europe. However, when tools are adapted to other countries, data may need to be adapted because standards and approaches vary between countries.

\section{Voluntary environmental agreements have become increasingly popular}

Voluntary environmental agreements are typical of the type of sustainable building policies established in the Netherlands. The 2000 survey shows that most of the environmental agreements entered into by housing associations are with municipalities. These agreements focus on energy conservation, but are also expanding to include other aspects of sustainable building. Voluntary agreements may be of interest as sustainable building policies in Germany, France, the UK and Finland. The agreement between the social housing sector and the government described here could be adapted for the social housing sector in France or the UK. Considering the entire process of introducing the objectives of agreements at the housing association level, it might be useful to structure their own, rather vague, environmental policies.

\section{Small housing associations are more passive than their larger counterparts}

In the cross-analyses, a correlation was found between the size of association and their implementation of sustainable measures. The more dwellings a housing association manages, the more likely it is to have an environmental policy, to establish sustainable building agreements with third parties and to offer its tenants environmental education. Housing associations with an environmental policy are approximately one-third larger on average than those with no such policies. Twenty per cent of the small housing associations have environmental policies compared with $50 \%$ of the large associations. Although based on the Dutch situation, other European countries can note that different target groups should be recognized in sustainable building policies and objectives should be specified according to their own needs.

\section{Lack of market demand}

The Dutch housing associations name subsidies as the most important measure to promote sustainable building in the 2000 survey. However, it is unrealistic to think that subsidies alone can increase sustainable building. The real threat to sustainable building is the lack of market demand. According to the SBR market research study (2001), very few consumers are willing to make any extra investments in sustainable building in the Netherlands, and many have no interest whatsoever in it. On the other hand, housing associations have not invested sustained effort in the environmental education of tenants, whose actions have a major environmental impact on the social housing sector. This problem of low demand should be taken seriously and ways to change general values and consumption habits to be more sustainable need to be searched for.

\section{Recommendations \\ Housing associations need consistent environmental policies}

According to the 2000 survey, several housing associations are planning to adopt an environmental policy in the Netherlands over the next 5 years. Successful examples of such policies could serve as an aid to these associations achieving this objective. In larger housing associations, standardized and international environmental management systems, such as the ISO 14001 or EMAS, can ensure an effective and consistent policy. 


\section{Small housing associations need motivation}

The cross-analyses show that large housing associations are more active than their smaller counterparts in the Netherlands. Therefore, it is important to include small housing associations in sustainable building policies. Since the managerial needs of small and large housing associations can differ, efforts to encourage small associations may require policy adjustments.

\section{Environmental education of tenants}

The operation phase and tenants can play a key role in reducing the environmental impact of the social housing sector in every country. Housing associations should be encouraged to educate their tenants. It is not necessary for housing associations to produce environmental educational materials. More use of existing materials produced by other organizations, e.g. the Ministry of the Environment, is required on sustainable building and lifestyles. The information they provide should be clear and interesting to the target audiences.

\section{More focus on the existing stock}

To achieve the objectives in the national strategy for sustainable building, such as those regarding energy conservation, environmental policies need to engage with managing and renovating the existing stock. This applies both to government policies and strategies at the housing association level in all five countries analysed. Projects in the existing stock require systematic environmental policies and agreements with third parties. Current environmental agreements between housing associations and municipalities, to name one example, focus on new construction. Their scope, however, should extend to include targets for the existing stock as well.

\section{Social and economic aspects need attention}

Although energy and material measures are relatively well considered in housing associations, social and economic aspects of sustainable housing need more attention. Affordability of housing, accessibility and safety are essential in achieving sustainable solutions in social housing. New measures such as adaptability and safety are increasingly associated with sustainable building in the Netherlands. However, social and economic aspects were not included in the sustainable building agreements and sustainable management tools that were described here.

\section{Environmental improvements require regulations as well as subsidies}

An efficient way of making housing associations take environmental action is to increase the use of mandatory measures. In practice, the standard set by building regulations is seldom exceeded without extra benefits in the Netherlands. Therefore, the target level of the current standards should be considerably raised. However, regulations can never affect the majority of buildings, since they apply primarily to new construction. Other measures, such as taxes, are also needed and environmental objectives should be included in housing subsidy criteria. Given the objective of affordability in social housing, more stringent measures and regulations must be counter-balanced by subsidies.

Again, the basic problem is the lack of market demand. Sustainable building is not a market asset and this situation needs to be changed. One concrete way to green the market could be the environmental labelling of houses. Energy labels for domestic appliances have increased sales of the A-labelled goods, which are associated with good quality and long-term savings. An environmental label for buildings could assure consumers that they get value for their investment and increase interest in sustainable building. A standardized label could also reduce confusion in a growing market of different consultation and evaluation services.

\section{Focus on the process}

The development of instruments is not enough to promote sustainable building because much depends on the implementation process, e.g. Dutch housing associations named lack of knowledge as an important barrier. Despite the availability of the instruments, a gap exists between government policy and practice. For example, one reason for the slow adaptation of sustainability improvements is housing associations have to make the investments whereas the tenants profit from a less expensive energy bill. The capture of benefits needs to be employed to motivate housing associations.

\section{Implementation of environmental agreements needs control}

The environmental agreement and its survey programme in the Dutch social housing sector aims to give sustainable management a precise and concrete form. However, when sustainable building is promoted with voluntary agreements and policy plans, a signed agreement does not necessarily guarantee any more 
action in practice. For example, housing associations with an environmental policy are not necessarily more active in implementing measures than those with no such policies. Therefore, documentation of the implementation of objectives is essential if the Dutch approach of voluntary agreements is adopted in other countries.

\section{Focus on target groups}

A gap exists between government policy and its implementation in practice, primarily by the barrier of costs recognized in all five countries analysed. One approach to the conflict between environmental and economic values is to divide the housing associations into different target groups, e.g. Leaders, Platoon and Laggers. Different tools can be applicable for each target group. Additional research is needed to specify more precisely the different target groups and their applied tools in making housing associations take environmental action in practice.

\section{References}

Association HQE (2000) La HQE (Haute Qualité Environnementale) dans les bâtiments en 21 questions/ réponses, Association $\mathrm{HQE}$, Paris.

Atrivé (1998) Monitor convenant duurzaam bouwen, Novem/ Atrivé, Zeist.

Atrivé (2001) Monitor convenant duurzaam bouwen, Novem/ Atrivé, Zeist.

Blaauw, K. and Klunder, G. (1999) Duurzame Woningbouw in de Ecologische Stad, Delft University Press, Delft.

Bourdeau, L. (ed.) (1999) Agenda 21 on Sustainable Construction, Report 237, CIB, Rotterdam.

Delebarre, M. (2000) Développement durable, un enjeu majeur pour les HLM. Habitat et société, no. 20, 17.

DETR (Department of the Environment, Transport and Regions) (2000) Building a Better Quality of Life, Sustainable Development Strategy, DETR, London.

Federal Statistical Office (2001) http://www.Statistik-bund.de

Haffner, M. and Dol, C. (2000) Housing Statistics in the European Union 2000, Ministerie van VROM, The Hague.

Liimatainen, M. (1995) Saksa, Energiansäästö-, ympäristö ja ekologiavaatimukset, RTT, Helsinki.

Luten, M.R. and Van Bakel, A.G.J.M. (1997) Duurzaam beheer, Milieuberaad Bouw, Utrecht.
MVROM (Ministerie van Volkshuisvesting, Ruimtelijke Ordening en Milieubeheer) (1995) Plan van aanpak duurzaam bouwen. Investeren in de toekomst, Ministerie van VROM, The Hague.

MVROM (Ministerie van Volkshuisvesting, Ruimtelijke Ordening en Milieubeheer) (1997) Tweede plan van aanpak duurzaam bouwen, Ministerie van VROM, The Hague.

Quintis (1999) Handleiding duurzaam bouwen en beheren, November/Aedes, Sittard.

Quist, H.J. and van den Broeke, R.A. (1994) Duurzaamheid en het beheer van de woningvoorraad, Delft University Press, Delft.

SBR (Stichting Bouwresearch) (1998a) Nationaal pakket duurzaam bouwen nieuwbouw, SBR, Rotterdam.

SBR (Stichting Bouwresearch) (1998b) Nationaal pakket duurzaam bouwen beheer, SBR, Rotterdam.

SBR (Stichting Bouwresearch) (2001) Attitude t.a.v. duurzaam bouwen en Nationaal Pakket WoningbouwUtiliteitsbouw, SBR, Rotterdam.

SEV (Stuurgroep Experimenten Volkshuisvesting) (1997) Duwon; duurzaam woningbeheer, SEV/November, Rotterdam/Sittard.

Sunikka, M. (2001) Policies and Regulations for Sustainable Building: A Comparative Analysis of Five European Countries, Delft University Press, Delft.

Sunikka, M. and Boon, C. (2002) Housing Associations and Sustainable Management: Environmental Efforts in the Netherlands' Social Housing Sector, Delft University Press, Delft.

Sunikka, M. and Klunder, G. (2001) Environmental Assessment in the Built Environment: The Dutch and the Finnish Approach, in HSA Conference Housing and the Environment, 18-19 April, York, UK.

The Housing Corporation (2000) The Housing Corporation Environmental Policy Statement, The Housing Corporation, London.

Waals, J.F.M. van der, Vermeulen, S.M.J., Vermeulen, W.J.V., Glasbergen, P. and Hooimeijer, P. (2000) Energiebesparing en stedelijke herstructurering, een beleidswetenschappelijke analyse, DGVH/NETHUR 10, Utrecht.

Weismann, L. (2000) Stand van zaken en trends in duurzaam woningbeheer, Delft University Press, Delft, pp. 15-17.

Ympäristöministeriö (1998) Ekologisesti kestävän rakentamisen ohjelma, Ympäristöministeriö, Helsinki.

\section{Endnote}

${ }^{1}$ The EPC measures energy performance in buildings. It may not exceed a certain fixed value defined in the Dutch Building Decree. 